\title{
Research Note \\ The Energy Costs of the Ecotourism Summit in Quebec
}

\author{
Susanne Becken \\ Environment, Society and Design Division, Lincoln University, Canterbury, \\ New Zealand
}

\section{Introduction}

The Ecotourism Summit, one of the main events of the International Year of Ecotourism 2002, was said by the World Tourism Organisation (2002) to have been a 'huge success', with delegates from 133 different countries. However, the energy demand of the delegates' (long-distance) travel to Quebec was apparently not taken into account. The Ecotourism Summit, therefore, is an example of 'good intentions' and conference travel resulting in environmental impacts, in this case greenhouse gas emissions. In the light of the possible ratification of the Kyoto Protocol (to reduce man-made greenhouse effects) later in 2002, the lack of any mitigation efforts on the part of the Ecotourism Summit is remarkable, and demonstrates that the consequences of international air travel are still ignored by (ecotourism) researchers and other stakeholders. In this note, the Ecotourism Summit will be used to illustrate the points made by Høyer and Naess (2001). The energy use involved to transport all delegates from their home countries to Quebec, and back home again will be estimated as well as the resulting $\mathrm{CO}_{2}$ emissions.

\section{Method}

A delegate list was used to retrace the flights of delegates from their home countries, assuming travel from the airport at the relevant capital city (where possible). Travel distances for flights between the home country and Quebec were retrieved from a web-based airfare wholesaler, providing information on routings, airfares and mileages. The cheapest (not the shortest) of several travel options was chosen. In the case of visitors from the USA, it was simplified so that half of the delegates were assumed to have travelled from Los Angeles to Quebec, and the other half from New York. Similarly, for Canadian visitors half were assumed to have flown to Quebec from Montreal, and the other half from Toronto. Delegates from international organisations (a total of 48) were allocated the average distance of all other countries of origin ( $9463 \mathrm{~km}$ one way). The travel distances were converted into energy use applying a factor of 2 megajoules (MJ) per passenger-revenue kilometre (British Airways, 2001; Lenzen, 1999) and $\mathrm{CO}_{2}$ emissions were derived using a factor of $69 \mathrm{~g} \mathrm{CO}_{2}$ per MJ of kerosene (Becken, 2002). 


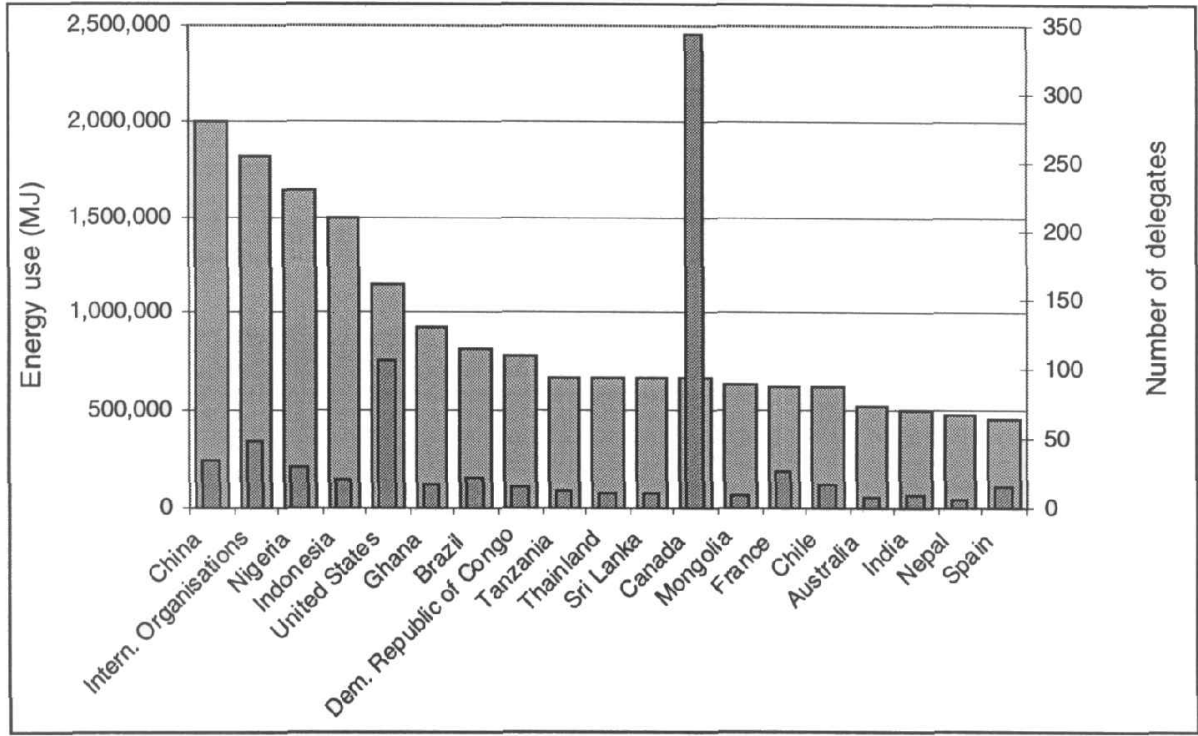

Figure 1 Energy use and delegates from most energy consuming countries

\section{Result and Discussion}

These calculations suggest that the 1164 delegates from 133 countries consumed 29.8 terajoules (TJ). This energy use is equivalent to the emission of 2,057 tonnes of $\mathrm{CO}_{2}$. The average delegate consumed 37,850 MJ. The largest energy use was associated with travel from Indonesia $(71,260 \mathrm{MJ})$, a result of the long distance between Jakarta and Quebec but also of indirect routing involving several connecting flights. Indonesia, with a delegation of 21, was the fourth largest energy consumer after China, international organisations and Nigeria (Figure 1). Canada, with a delegation of 343, was responsible for the consumption of $0.6 \mathrm{TJ}$ or $2 \%$ of all energy use.

Most delegates came from North America (39\%), using about 6\% of the total energy use for air travel. Visitors from the Asian and African continents were large energy consumers, making up more than half of the almost $30 \mathrm{TJ}$ (Figure 2).

The energy use of almost $30 \mathrm{TJ}$ for air travel to the Ecotourism Summit could sustain 2095 Nepali citizens, 432 world citizens or 90 Canadians (IEA, 2001) for a whole year. It could well be argued, therefore, that the promotion of web conferences could be further enhanced to take some pressure off the environment. A good example was the Sustainable Development of Ecotourism Web-Conference between 1st and 26th of April 2002 that was 'attended' by a similar number of interested parties (WTO, 2002). Since it is obviously indispensable, however, to hold some future international meetings for various purposes it will be critical to develop mechanisms to minimise and offset emissions resulting from air travel to such meetings. One option would be participation in forest restoration or tree-planting schemes for carbon sequestration or the making of a financial contribution to renewable energy fuel research or programmes. Creativity in this 


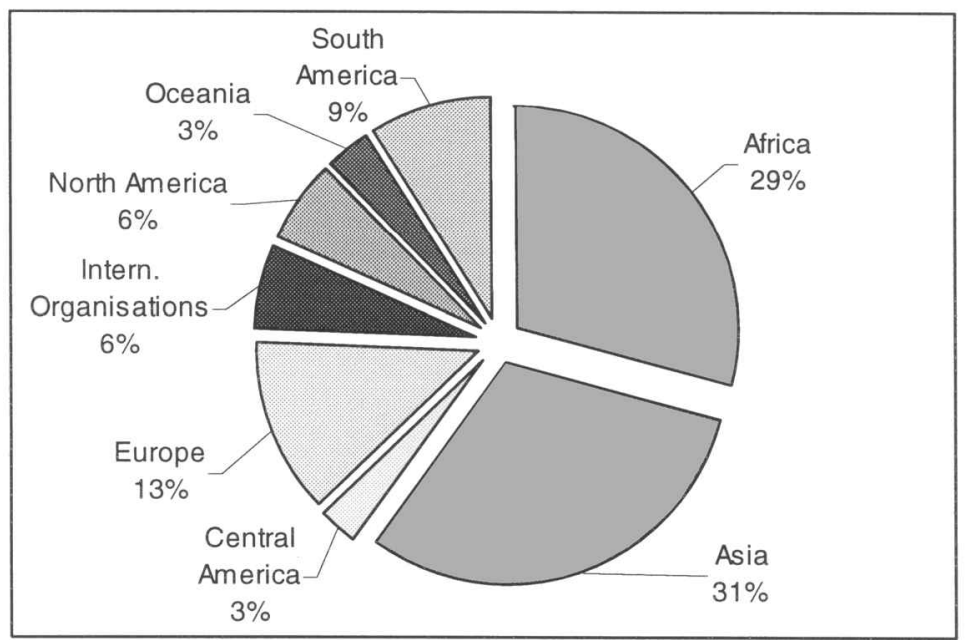

Figure 2 Contribution to total energy use of $30 \mathrm{TJ}$ by continent

regard could perhaps reasonably be expected from all future ecotourism or sustainable tourism conferences?

\section{Correspondence}

Any correspondence should be directed to Dr Susanne Becken, Environment, Society and Design Division, PO Box 84, Lincoln University, Canterbury, New Zealand (beckens@Lincoln.ac.nz).

\section{References}

Becken, S. (2002) Analysing international tourist flows to estimate energy use associated with air travel. Journal of Sustainable Tourism 10 (2), 114-31.

British Airways (2001) From the ground up. Social and environmental report 2001. On WWW at http://www.britishairways.com/responsibility/docs/performing/ report_2001.pdf. Accessed 10.5.2002.

Høyer, K.G. and Naess, P. (2001) Conference tourism: A problem for the environment, as well as for research? Journal of Sustainable Tourism 9 (6), 451-70.

IEA (2001) Key world energy statistics 2001. On WWW at www.iea.org/statist. Accessed 25.7.2002.

Lenzen, M. (1999) Total requirements of energy and greenhouse gases for Australian transport. Transportation Research Part D 4D (4), 265-90.

WTO (2002)Homepage. On WWW at http:/ / www.world-tourism.org. Accessed 24.7.2002. 